\title{
WestVirginiaUniversity.
}

Department of Economics

Working Paper Series

\section{An Ordinal Ranking of Economic Institutions}

Scott Beaulier, Robert Elder, Cheryl Han and Joshua Hall

Working Paper No. 15-12

This paper can be found at the College of Business and Economics

Working Paper Series homepage: 


\title{
An Ordinal Ranking of Economic Institutions
}

\author{
Scott Beaulier \\ W.P. Carey School of Business \\ Arizona State University \\ Scott.Beaulier@asu.edu \\ Robert Elder \\ Department of Economics \\ Beloit College \\ elder@beloit.edu \\ Cheryl Han \\ Department of Economics \\ Beloit College \\ Joshua C. Hall \\ Associate Professor of Economics \\ College of Business and Economics \\ West Virginia University \\ joshua.hall@mail.wvu.edu
}

\begin{abstract}
We provide the first ranking of countries' economic institutions using an ordinal methodology. Using the five areas of the Fraser Institute's Economic Freedom of the World (EFW) Index, we find that final rankings of a country's institutions are sensitive to the importance-ordering of Area 1 (Size of Government). When Areas 2-5 are in the most important position, we find that there is no significant difference between the EFW rankings and our rankings. When Area 1 is placed in the most important position, however, a number of European countries with large welfare states but good governance do poorly.
\end{abstract}

JEL Codes: E02, 043

Keywords: economic freedom; ordinal; net dominance metric

Acknowledgements: We thank workshop participants in Suffolk University's Department of Economics for helpful comments and suggestions. Bob Elder and Cheryl Han benefited from the Sanger Summer Scholars program at Beloit College, and they sincerely thank Jim and Marge Sanger for financial support. The authors also thank Ann Davies, Robert Lawson, Dan Sutter, Charles Westerberg, and Rachael Wogsland for their helpful comments. The contents of the paper are the sole responsibility of the authors, and they do not reflect the views of Jim and Marge Sanger or those who administer the Sanger Summer Scholars program at Beloit College. Hall would like to acknowledge that a portion of this work occurred while he was a Big XII Fellow at Texas Tech University with the Free Market Institute. 


\section{An Ordinal Ranking of Economic Institutions}

\section{Introduction}

Each year, the Fraser Institute's Economic Freedom of the World (EFW) annual report

(Gwartney et al. 2014) measures and ranks the economic freedom of 152 different

countries around the world. The rank is based on a summary index with scores ranging

from a value of 0 to 10 , with higher scores reflecting more economic freedom. The index

is determined by average scores earned in five areas: (1) Size of Government:

Expenditures, Taxes, and Enterprises; (2) Legal Structure and Property Rights; (3)

Access to Sound Money; (4) Freedom to Trade Internationally; and (5) Regulation of

Credit, Labor, and Business. The EFW has been used as a measure of institutions in

hundreds of scholarly papers (Hall and Lawson 2014).

The EFW report's index score for any particular country is the simple average of the cardinal scores in the five areas. In the EFW report, Gwartney et al. $(2009,9)$ reflect on how the five areas of economic freedom are weighted:

Theory provides us with direction regarding elements that should be included in the five areas and the summary index, but it does not indicate what weights should be attached to the components within the areas or among the areas in the construction of the index. It would be nice if these factors were independent of each other and a weight could be attached to them. During the past several years, we have investigated several methods of weighting the various components, including principle component analysis and a survey of economists. We have also invited others to use their own weighting structure if they believe that is preferable. In the final analysis, the summary index is not very sensitive to substantial variations in the weights.

We examine the index's sensitivity by using an alternative ranking methodology.

Like previous attempts to generate alternative EFW aggregates (Sturm et al. 2002,

Caudill et al. 2000, Heckelman and Stroup 2000), our approach produces a different 
summary index, and this alternative index allows us to rank countries according to their relative levels of economic freedom. The main benefit of our approach is that we eschew cardinal weights across areas of the freedom index in favor of an ordinal approach. As pioneered by Cherchye and Vermeulen (2006) and adapted by Beaulier and Elder (2011), we employ a Net Dominance Metric (NDM), or "dominetric" that relies upon the importance-ordering of the five areas of the EFW. In this regard, our work is similar to Hall and $\mathrm{Yu}$ (2012) who use the dominetric approach to provide an alternative ranking of the institutions of US state governments.

Although Gwartney, Lawson, and Hall $(2009,9)$ note that "the summary index is not very sensitive to substantial variations in the weights," our NDM approach produces economic freedom rankings that are sensitive to the importance-ordering of the five areas. In particular, our dominetrics reveal Area 1 (Size of Government: Expenditures, Taxes, and Enterprises) to be very different than Areas 2-5. While the NDM and the equally-weighted EFW Index can serve as substitutes when Areas 2, 3, 4, or 5 are ordered as most important, the EFW Index and NDM are not substitutable when Area 1 is deemed most important.

In the next section, we describe our methodology. A complete set of our rankings appears in the Appendix, and a discussion of the salient aspects of our results occurs in Section 3. Section 4 concludes and provides additional commentary on the Area 1 effect.

\section{A Comparison between Cardinal and Ordinal Approaches}

Before reporting on similarities and differences between the EFW and NDM rankings, we first contrast the Cherchye and Vermeulen (2006) ranking methodology with the 
Gwartney et al. (2014) methodology. Consider two hypothetical countries, A and B, and let $\mathrm{S}_{1}^{\mathrm{A}}$ denote Country A's EFW score in Area $1, \mathrm{~S}_{1}^{\mathrm{B}}$ denote Country B's EFW score in Area 1, $\mathrm{S}_{2}^{\mathrm{A}}$ denote Country A's EFW score in Area 2, and so on. Since the EFW summary index for any country equals its average score across the five dimensions of performance, its overall score emerges from a cardinal-weighting scheme. For example, Country A's EFW Summary Index $=0.2 \mathrm{~S}_{1}^{\mathrm{A}}+0.2 \mathrm{~S}_{2}^{\mathrm{A}}+0.2 \mathrm{~S}_{3}^{\mathrm{A}}+0.2 \mathrm{~S}_{4}^{\mathrm{A}}+0.2 \mathrm{~S}_{5}^{\mathrm{A}}$. Country A would have a higher EFW rank than Country B if $0.2 \mathrm{~S}_{1}^{\mathrm{A}}+0.2 \mathrm{~S}_{2}^{\mathrm{A}}+0.2 \mathrm{~S}_{3}^{\mathrm{A}}+$ $0.2 \mathrm{~S}_{4}^{\mathrm{A}}+0.2 \mathrm{~S}_{5}^{\mathrm{A}}>0.2 \mathrm{~S}_{1}^{\mathrm{B}}+0.2 \mathrm{~S}_{2}^{\mathrm{B}}+0.2 \mathrm{~S}_{3}^{\mathrm{B}}+0.2 \mathrm{~S}_{4}^{\mathrm{B}}+0.2 \mathrm{~S}_{5}^{\mathrm{B}}$.

A simple average is one way to combine the area scores to form a rating and then a ranking. The Cherchye and Vermeulen (2006) approach is another method, and it relies on an importance-ordering imposed upon the five areas of performance. Suppose someone deems Area 3 of the EFW report to be the most important dimension of economic freedom, Area 5 to be second most important, Area 2 to be third most important, Area 1 to be fourth most important, and Area 4 to be fifth most important. Let this person's importance-ordering be denoted by the 5-tuple $(3,5,2,1,4)$. Country A "dominates" Country B if all the following criteria are satisfied:

Criterion 1: $\mathrm{S}_{3}^{\mathrm{A}} \geq \mathrm{S}_{3}^{\mathrm{B}}$;

Criterion 2: $\mathrm{S}_{3}^{\mathrm{A}}+\mathrm{S}_{5}^{\mathrm{A}} \geq \mathrm{S}_{3}^{\mathrm{B}}+\mathrm{S}_{5}^{\mathrm{B}}$;

Criterion 3: $\mathrm{S}_{3}^{\mathrm{A}}+\mathrm{S}_{5}^{\mathrm{A}}+\mathrm{S}_{2}^{\mathrm{A}} \geq \mathrm{S}_{3}^{\mathrm{B}}+\mathrm{S}_{5}^{\mathrm{B}}+\mathrm{S}_{2}^{\mathrm{B}}$;

Criterion 4: $\mathrm{S}_{3}^{\mathrm{A}}+\mathrm{S}_{5}^{\mathrm{A}}+\mathrm{S}_{2}^{\mathrm{A}}+\mathrm{S}_{1}^{\mathrm{A}} \geq \mathrm{S}_{3}^{\mathrm{B}}+\mathrm{S}_{5}^{\mathrm{B}}+\mathrm{S}_{2}^{\mathrm{B}}+\mathrm{S}_{1}^{\mathrm{B}}$;

Criterion 5: $\mathrm{S}_{3}^{\mathrm{A}}+\mathrm{S}_{5}^{\mathrm{A}}+\mathrm{S}_{2}^{\mathrm{A}}+\mathrm{S}_{1}^{\mathrm{A}}+\mathrm{S}_{4}^{\mathrm{A}} \geq \mathrm{S}_{3}^{\mathrm{B}}+\mathrm{S}_{5}^{\mathrm{B}}+\mathrm{S}_{2}^{\mathrm{B}}+\mathrm{S}_{1}^{\mathrm{B}}+\mathrm{S}_{4}^{\mathrm{B}}$. 
The most important dimension of performance (here Area 3) affects all five criteria, the next most important (here Area 5) affects four of the criteria, and so on.

Domination can be achieved in the absence of Pareto-superiority. For Country A to be Pareto-superior to Country B, the following criteria would have to be satisfied, and at least one of the following weak inequalities would have to be replaced with a strong inequality.

$$
\begin{aligned}
& \text { Criterion 1: } \mathrm{S}_{1}^{\mathrm{A}} \geq \mathrm{S}_{1}^{\mathrm{B}} \text {; } \\
& \text { Criterion 2: } \mathrm{S}_{2}^{\mathrm{A}} \geq \mathrm{S}_{2}^{\mathrm{B}} \text {; } \\
& \text { Criterion 3: } \mathrm{S}_{3}^{\mathrm{A}} \geq \mathrm{S}_{3}^{\mathrm{B}} \text {; } \\
& \text { Criterion 4: } \mathrm{S}_{4}^{\mathrm{A}} \geq \mathrm{S}_{4}^{\mathrm{B}} \text {; } \\
& \text { Criterion 5: } \mathrm{S}_{5}^{\mathrm{A}} \geq \mathrm{S}_{5}^{\mathrm{B}} \text {. }
\end{aligned}
$$

Given the importance-ordering $(3,5,2,1,4)$, Criterion 1 for domination and Criterion 3 for Pareto-superiority are the same: $\mathrm{S}_{3}^{\mathrm{A}} \geq \mathrm{S}_{3}^{\mathrm{B}}$. In addition, if Criterion 5 for Paretosuperiority $\left(\mathrm{S}_{5}^{\mathrm{A}} \geq \mathrm{S}_{5}^{\mathrm{B}}\right)$ is violated, Criterion 2 for domination $\left(\mathrm{S}_{3}^{\mathrm{A}}+\mathrm{S}_{5}^{\mathrm{A}} \geq \mathrm{S}_{3}^{\mathrm{B}}+\mathrm{S}_{5}^{\mathrm{B}}\right)$ still can be satisfied if $\mathrm{S}_{3}^{\mathrm{A}}-\mathrm{S}_{3}^{\mathrm{B}} \geq \mathrm{S}_{5}^{\mathrm{B}}-\mathrm{S}_{5}^{\mathrm{A}}$. Here we have an illustration of Cherchye and Vermeulen's compensation principle: even when two countries are Pareto-unrankable, one country still can dominate the other if its advantage in the more important dimension of performance is greater than or equal to its disadvantage in the less important dimension of performance.

Finally, a Net Dominance Metric is determined for any given country by taking the difference between the quantity of countries it dominates and the quantity of countries it is dominated by. Countries are then ranked by their dominetric totals, from highest to 
lowest. The following short numerical example illustrates the ordinal methodology described above.

Consider the four countries in the Southern Common Market, or MERCOSUR. Suppose again that a hypothetical consumer of the EFW report has a preferred importance-ordering given by $(3,5,2,1,4)$. The first column of Table 1 lists MERCOSUR's four member states alphabetically. The next five columns show EFW Area Scores $S_{i}$ earned for the year 2007. In the final five columns of Table $2, \Sigma_{j}$ denotes the sum of scores earned by each country in the $\mathrm{j}$ most important areas.

Since $\mathrm{S}_{3}^{\text {Uruguay }}>\mathrm{S}_{3}^{\text {Brazil }}$ and $\mathrm{S}_{5}^{\text {Uruguay }}>\mathrm{S}_{5}^{\text {Brazil }}$ and $\mathrm{S}_{2}^{\text {Uruguay }}>\mathrm{S}_{2}^{\text {Brazil }}$ and $\mathrm{S}_{1}^{\text {Uruguay }}>\mathrm{S}_{1}^{\text {Brazil }}$ and $\mathrm{S}_{4}^{\text {Uruguay }}>\mathrm{S}_{4}^{\text {Brazil }}$, the first five columns of Table 2 reveal Uruguay's economic freedom to be Pareto-superior to Brazil's. Given the satisfaction of the preceding inequalities, the inequalities $\Sigma_{1}^{\text {Uruguay }}>\Sigma_{1}^{\text {Brazil }}, \Sigma_{2}^{\text {Uruguay }}>\Sigma_{2}^{\text {Brazil }}, \Sigma_{3}^{\text {Uruguay }}>\Sigma_{3}^{\text {Brazil }}$, $\Sigma_{4}^{\text {Uruguay }}>\Sigma_{4}^{\text {Brazil }}$, and $\Sigma_{5}^{\text {Uruguay }}>\Sigma_{5}^{\text {Brazil }}$ necessarily hold (as confirmed by the final five columns of data in Table 2). Therefore, by the Cherchye-Vermeulen criteria, Uruguay's economic freedom dominated Brazil's economic freedom in 2007.

If we compare Uruguay with Argentina, however, we note that although $\mathrm{S}_{3}^{\text {Uruguay }}>\mathrm{S}_{3}^{\text {Argentina }}, \mathrm{S}_{5}^{\text {Uruguay }}>\mathrm{S}_{5}^{\text {Argentina }}, \mathrm{S}_{2}^{\text {Uruguay }}>\mathrm{S}_{2}^{\text {Argentina }}$, and $\mathrm{S}_{4}^{\text {Uruguay }}>\mathrm{S}_{4}^{\text {Argentina }}$, the fact that $\mathrm{S}_{1}^{\text {Uruguay }}<\mathrm{S}_{1}^{\text {Argentina }}$ makes Uruguay and Argentina Pareto-unrankable. Nevertheless, the inequalities $\Sigma_{1}^{\text {Uruguay }}>\Sigma_{1}^{\text {Argentina }}$ and $\Sigma_{2}^{\text {Uruguay }}>\Sigma_{2}^{\text {Argentina }}$ and $\Sigma_{3}^{\text {Uruguay }}>\Sigma_{3}^{\text {Argentina }}$ and $\Sigma_{4}^{\text {Uruguay }}>\Sigma_{4}^{\text {Argentina }}$ and $\Sigma_{5}^{\text {Uruguay }}>\Sigma_{5}^{\text {Argentina }}$ are all satisfied, Uruguay's economic freedom dominated Argentina's economic freedom. From the Uruguay-Brazil example, a Paretorelationship necessarily implies a dominance relationship; from the Uruguay-Argentina 
example, a dominance relationship can exist in the absence of a Pareto relationship. And, to reiterate: Dominance relationships occur more frequently than Pareto relationships because of the compensation principle. In the case above, the amount by which Uruguay out-performs Argentina in the three most important areas (here, areas 3, 5, and 2) more than compensates for the amount by which Argentina out-performs Uruguay in the fourth most important area (here, area 1):

$$
\Sigma_{3}^{\text {Uruguay }}-\Sigma_{3}^{\text {Argentina }}=19.94-16.08=3.86>0.02=7.43-7.41=\mathrm{S}_{1}^{\text {Argentina }}-\mathrm{S}_{1}^{\text {Uruguay }}
$$

The compensation principle cannot always transform a Pareto-unrankable pair into a dominance-rankable pair. For instance, let us look at Uruguay and Paraguay. First we see $\mathrm{S}_{3}^{\text {Paraguay }}=8.24>8.10=\mathrm{S}_{3}^{\text {Uruguay }}$ but $\mathrm{S}_{5}^{\text {Paraguay }}=5.41<6.00=\mathrm{S}_{5}^{\text {Uruguay }}$. Uruguay and Paraguay are, therefore, Pareto-unrankable. In addition, the amount $(8.24-8.10=0.14)$ by which Paraguay outperforms Uruguay in the most important area (here area 3 ) fails to compensate for the amount $(6.00-5.41=0.59)$ by which Uruguay outperforms Paraguay in the second most important area (here area 5). Therefore, Uruguay and Paraguay are also dominance-unrankable.

Finally, the Net Dominance Metric is simply the quantity of countries dominated minus the quantity of countries dominated by. Therefore, NDMs can be calculated through the construction of a matrix with 1, 0, or -1 elements. As we can see in Table 2, for any cell with a 1 , the row country dominates the column country. Uruguay dominates Brazil and Argentina, so the Uruguay row shows a 1 in the Brazil column as well as a 1 in the Argentina column. For any cell with a 0, no dominance relationship exists. Since Uruguay and Paraguay are dominance-unrankable, the Uruguay row shows a 0 in the Paraguay column, and the Paraguay row shows a 0 in the Uruguay column. For any cell 
with a -1 , the row country is dominated by the column country. Since Brazil and Argentina are each dominated by Uruguay, $\mathrm{a}-1$ appears in the Brazil row and Uruguay column, and a -1 appears in the Argentina row and Uruguay column. In general, any (row x, column y) element and any (row y, column x) element must sum to zero. Finally, since any country's Net Dominance Metric equals countries dominated minus countries dominated by, the dominetric can be obtained simply by summing the $1 \mathrm{~s}, 0 \mathrm{~s}$, and $-1 \mathrm{~s}$ across the country's row. The resulting dominetrics (NDM) for our 4-country MERCOSUR example are shown in the final column of Table.

\section{Economic Freedom Country Rankings Generated through Ordinal Approaches}

In the preceding example, Uruguay's Net Dominance Metric would earn it a $1^{\text {st }}$ place economic freedom ranking in MERCOSUR; Brazil's and Paraguay's dominetrics of 0 would produce a tie for $2^{\text {nd }}$ place; and Argentina's NDM of -2 would yield a last place finish. The data we use to provide this 4-country example are part of the much larger EFW report. In the remainder of our analysis we use the chain-linked EFW data for 122 countries in 2007. Given a set of 122 countries, NDMs span the range from a maximum of 121 to a minimum of - 121. (We also have calculated the same NDMs for the same set

of countries in 2000 and have similar results as reported in the remainder of this paper.)

Given the existence of five dimensions of performance, there are 120 different importance-orderings (5-factorial different orderings) that can be used to obtain the NDMs upon which country rankings can be based. Any particular reader of the EFW report might have his or her own preferred importance-ordering. Subsequently, for each 
year we group the 24 sets of NDM results when Area 1 is assumed most important, the 24 sets of NDM results when Area 2 is assumed most important, etc. Average NDM results over each set of 24 outcomes are then obtained for each of the five cases and are presented in Appendix Tables A1-A5.

To get a better sense of how our rankings compare to the EFW, Table 3 compares average summary rankings from Tables A1-A5 with the EFW ranking for the countries ranked 1-40 in 2007. The first (far left) column of Table 3 shows the EFW chain-linked ranking in 2007; the remaining columns show a country's NDM rank when EFW areas 15 are most important. As can be seen, while a country's EFW ranking and NDM ranking in Area 2-5 is close in most cases, Area 1 is a different matter. For example, Denmark, which never scores lower than 21 in any other ranking, is 72 when Area 1 is most important. Austria, which never ranks lower than 15, ranks 47 when Area 1 is most important. Finland, which never ranks lower than 29, ranks 63 when Area 1 is most important.

To explore the potential substitutability of EFW and NDM rankings, first consider a hypothetical reader of the EFW report who thinks Area 4, Freedom to Trade Internationally, is the more important dimension of economic freedom. Then, given a linear regression model of the form,

NDM Rank (Area 4 Most Important) $)_{i}=\beta_{1}+\beta_{2}$ EFW Rank R $_{i}$, the null hypothesis of no significant difference between the EFW ranking and the NDM ranking (Area 4 most important) can be tested by $\mathrm{H}_{0}: \beta_{1}=0$ and $\mathrm{H}_{0}: \beta_{2}=1$. In other words, failure to reject the null hypotheses of a vertical intercept of zero and a slope of one is a failure to reject the null hypothesis that the $45^{\circ}$ line best fits the relationship 
between these two rankings. If we can infer that the $45^{\circ}$ line is the line of best fit, we must also infer that NDM rankings, when Area 4 is most important, do not provide a significantly different product from the EFW rankings that already exist.

Table 4 highlights results from five such regressions estimated for the year 2007. In each regression, the EFW country rank provides the explanatory variable. The dependent variable in each set of five regressions is the NDM country rank when Area 1, 2, 3, 4, or 5 is most important. When Areas 2, 3, 4, or 5 were treated as most important, $\beta_{1}=0$ resides inside each $99 \%$ confidence interval, and $\beta_{2}=1$ resides inside each $99 \%$ confidence interval as well. Thus, we fail to reject the null hypothesis that the EFW rank can be used to fit the NDM rank with a $45^{\circ}$ line in the year 2000 as well as the year 2007 , and in both of these years we therefore infer that there is no significant difference between the EFW product and the NDM product for any consumer of economic freedom rankings whose subjective belief is that Area 2, 3, 4, or 5 is the most important dimension of economic freedom. Moreover, the EFW rank explains $86.2 \%$ to $93.6 \%$ of the variation in the NDM rank in these eight regressions.

When we treat Area 1 as the most important dimension, however, the EFW rank explains only $48.8 \%$ of the variation in the NDM rank in 2000 and $56.6 \%$ of the variation in the NDM rank in 2007. Given the $99 \%$ confidence intervals, we reject $\mathrm{H}_{0}: \beta_{1}=0$ and $\mathrm{H}_{0}: \beta_{2}=1$ in both 2000 and 2007, and therefore we also reject the null hypothesis that the fitted line is the $45^{\circ}$ line in each of the two years mentioned above. Thus, we reject the null hypothesis of no significant difference between the EFW rankings and the NDM rankings when Area 1 is deemed most important. 
Figure 1 illustrates a scenario where the dependent variable remains the Area 1 NDM rank. We see the regression line fitted through the scatter of 122 observations for the year 2007. Observations from the European Union are highlighted. In 2007, we find Cyprus, the Slovak Republic, Greece, U.K., Ireland, Estonia, and Lithuania below the fitted regression line. Twenty of the 27 E.U. countries maintain positive residuals, and many continue to reside along the upper periphery of the scatter. Given $\hat{\beta}_{1}=15.232$ and $\hat{\beta}_{2}=0.75233$, the fitted regression line for 2007 intersects the $45^{\circ}$ line at $\mathrm{EFW}$ rank $=$ 61.5. Once again, therefore, the best-performing 50 percent of countries in the EFW rankings are fitted above the $45^{\circ}$ line (and consequently are predicted to have worse Area 1 rankings), and once more the opposite remains true for the worst-performing 50 percent of countries.

To explore this further, Figure 2 displays NDM rankings from Tables A1 through A5 for the European countries that rank in the top 20 of world GDP per capita. A hockey stick pattern appears fairly clear for the year 2007. Countries with uniformly worse economic freedom rankings when Area 1 is deemed most important have steadfastly better economic freedom rankings when Areas 2, 3, 4, or 5 are deemed most important.

\section{Concluding Discussion}

Our analysis uses the ordinal ranking methodology from Cherchye and Vermeulen (2006) to rank the institutions of countries using the five areas of the EFW index. Our analysis could be pushed back one step further and be used to calculate NDMs using all 42 components of the EFW index, although this would become increasingly complex as our 
current 5 Area approach generates 120 different rankings. This complexity highlights one of the primary benefits of the weighting approach of the EFW, namely that of simplicity and transparency (Lawson, 2008). In terms of trade-offs, we find little difference between NDM rankings generated when Areas 2-5 of the EFW are considered to be most important and the overall EFW rankings.

We do find, however, that NDMs are sensitive to the position of Area 1 in the importance ordering. Moreover, we find the resulting economic freedom rankings that emerge from NDMs, which assume Area 1 to be most important, to be significantly different from rankings generated from the cardinal-based EFW summary index. Finally, these significantly-different Area-1-Most-Important rankings display a tendency to attribute relatively poor economic freedom performance in relatively high real GDP per capita European countries. From our perspective, this finding confirms and highlights what individuals using the EFW index have long known - that Area 1 (Size of Government) is different than the other four areas of the EFW.

This should not be taken as a criticism of the inclusion of Area 1 and its components. This area and its' components are clearly consistent with the negative liberty definition of economic freedom Gwartney et al. (2014) have used since the beginning (Gwartney and Lawson 2000). Our results serve as a reminder of three important points. First, economic freedom is not 'good stuff' (Bologna and Hall, 2014). It is a definition, rigorously applied. It is not a sign of a bad measurement to have areas or components of economic freedom that do not correlate positively with growth or other positive outcomes. For some people, the whole point of measuring economic freedom is to find what trade-offs between economic freedom and other goods and values might 
exist. Second, individuals vary in their preferences and for those individuals who strongly value a large government relative to other features of economic freedom, then equal weighting of areas is going to be an inappropriate measure for them as individuals. Third, Area 1 is unique among the five EFW areas in that it can help to support or retard the other areas of economic freedom (Bologna and Hall, 2014).

Our approach here helps to better understand the EFW measure of institutions and its limitations in a manner similar to the recent paper by Huskinson and Lawson (2015). While not directly addressing recent debates on how not to measure institutions (Voigt 2013; Shirley 2013; Robinson 2013), it does inform those debates. It could also be applied to other measures of institutions, such as the recent measure developed by Kunčič (2014). 
Table 1

An Example of the Transformation of EFW Area Scores into Dominetrics

\begin{tabular}{lcccccccccc}
\hline & $\mathrm{S}_{3}$ & $\mathrm{~S}_{5}$ & $\mathrm{~S}_{2}$ & $\mathrm{~S}_{1}$ & $\mathrm{~S}_{4}$ & $\Sigma_{1}$ & $\Sigma_{2}$ & $\Sigma_{3}$ & $\Sigma_{4}$ & $\Sigma_{5}$ \\
\hline Argentina & 7.11 & 5.11 & 3.86 & 7.43 & 6.39 & 7.11 & 12.22 & 16.08 & 23.51 & 29.91 \\
Brazil & 7.51 & 5.50 & 4.74 & 6.01 & 6.36 & 7.51 & 13.01 & 17.75 & 23.76 & 30.12 \\
Paraguay & 8.24 & 5.41 & 2.13 & 7.44 & 7.42 & 8.24 & 13.65 & 15.78 & 23.21 & 30.63 \\
Uruguay & 8.10 & 6.00 & 5.84 & 7.41 & 7.05 & 8.10 & 14.10 & 19.94 & 27.35 & 34.40 \\
\hline
\end{tabular}

Note: Given the importance-ordering $(3,5,2,1,4), \Sigma_{1}=\mathrm{S}_{3}, \Sigma_{2}=\mathrm{S}_{3}+\mathrm{S}_{5}, \Sigma_{3}=\mathrm{S}_{3}+\mathrm{S}_{5}+\mathrm{S}_{2}, \Sigma_{4}=\mathrm{S}_{3}+\mathrm{S}_{5}+\mathrm{S}_{2}+\mathrm{S}_{1}$, and $\Sigma_{5}$

$=\mathrm{S}_{3}+\mathrm{S}_{5}+\mathrm{S}_{2}+\mathrm{S}_{1}+\mathrm{S}_{4}$ 
Table 2

An Example of Dominance Relationships to NDM

\begin{tabular}{lccccc}
\hline Country & Argentina & Brazil & Paraguay & Uruguay & NDM \\
\hline Argentina & -- & -1 & 0 & -1 & -2 \\
Brazil & 1 & -- & 0 & -1 & 0 \\
Paraguay & 0 & 0 & -- & 0 & 0 \\
Uruguay & 1 & 1 & 0 & -- & 2 \\
\hline
\end{tabular}


Table 3

A Comparison of Rankings for Top 40 EFW Countries, 2007

\begin{tabular}{|c|c|c|c|c|c|c|}
\hline Country & EFW Rank & $\begin{array}{c}\text { Rank } \\
\text { When Area } \\
1 \text { Most } \\
\text { Important }\end{array}$ & $\begin{array}{c}\text { Rank } \\
\text { When Area } \\
2 \text { Most } \\
\text { Important }\end{array}$ & $\begin{array}{c}\text { Rank } \\
\text { When Area } \\
3 \text { Most } \\
\text { Important }\end{array}$ & $\begin{array}{c}\text { Rank } \\
\text { When Area } \\
4 \text { Most } \\
\text { Important }\end{array}$ & $\begin{array}{c}\text { Rank } \\
\text { When Area } \\
5 \text { Most } \\
\text { Important }\end{array}$ \\
\hline Hong Kong & 1 & 1 & 2 & 3 & 1 & 2 \\
\hline Singapore & 2 & 2 & 6 & 7 & 2 & 1 \\
\hline Switzerland & 3 & 3 & 3 & 2 & 28 & 5 \\
\hline New Zealand & 4 & 15 & 1 & 1 & 6 & 3 \\
\hline Chile & 5 & 4 & 21 & 13 & 3 & 4 \\
\hline Ireland & 6 & 19 & 7 & 5 & 4 & 12 \\
\hline United States & 7 & 9 & 16 & 4 & 10 & 6 \\
\hline United Kingdom & 8 & 18 & 11 & 11 & 12 & 9 \\
\hline Canada & 9 & 21 & 8 & 8 & 25 & 10 \\
\hline Australia & 10 & 17 & 5 & 9 & 34 & 14 \\
\hline Denmark & 11 & 72 & 10 & 21 & 15 & 8 \\
\hline Austria & 12 & 47 & 4 & 10 & 14 & 19 \\
\hline Estonia & 13 & 16 & 22 & 15 & 5 & 11 \\
\hline Mauritius & 14 & 5 & 18 & 19 & 16 & 21 \\
\hline Taiwan & 15 & 13 & 30 & 6 & 9 & 15 \\
\hline Oman & 16 & 59 & 19 & 31 & 21 & 7 \\
\hline Finland & 17 & 63 & 9 & 17 & 29 & 22 \\
\hline Unit. Arab Em. & 18 & 20 & 24 & 47 & 7 & 13 \\
\hline Netherlands & 19 & 78 & 17 & 22 & 13 & 25 \\
\hline Germany & 20 & 52 & 12 & 20 & 19 & 47 \\
\hline Cyprus & 21 & 22 & 20 & 18 & 27 & 35 \\
\hline Luxembourg & 22 & 74 & 14 & 25 & 17 & 40 \\
\hline Iceland & 23 & 26 & 15 & 49 & 62 & 17 \\
\hline Costa Rica & 24 & 10 & 25 & 36 & 20 & 48 \\
\hline Malta & 25 & 48 & 23 & 14 & 24 & 37 \\
\hline Norway & 26 & 53 & 13 & 35 & 51 & 34 \\
\hline Kuwait & 27 & 35 & 26 & 39 & 47 & 16 \\
\hline Slovak Rep & 28 & 30 & 37 & 27 & 8 & 31 \\
\hline Panama & 29 & 7 & 52 & 26 & 11 & 38 \\
\hline El Salvador & 30 & 6 & 67 & 30 & 35 & 20 \\
\hline Bahrain & 31 & 37 & 38 & 38 & 18 & 23 \\
\hline Korea & 32 & 33 & 33 & 12 & 42 & 32 \\
\hline Jordan & 33 & 54 & 39 & 37 & 23 & 26 \\
\hline France & 34 & 73 & 27 & 23 & 37 & 56 \\
\hline Japan & 35 & 51 & 29 & 16 & 64 & 33 \\
\hline Guatemala & 36 & 11 & 56 & 32 & 30 & 30 \\
\hline Hungary & 37 & 65 & 34 & 40 & 22 & 41 \\
\hline Portugal & 38 & 69 & 32 & 24 & 46 & 54 \\
\hline Lithuania & 39 & 28 & 45 & 45 & 36 & 29 \\
\hline Sweden & 40 & 91 & 28 & 41 & 39 & 49 \\
\hline
\end{tabular}


Table 4

OLS Estimation of the Equation NDM Rank $k_{i}=\beta_{1}+\beta_{2}$ EFW Rank $k_{i}+u_{i}$

$$
\text { Dependent Variable }
$$

$\beta_{1}: 99 \%$

Confidence

Interval

\begin{tabular}{|c|c|c|c|}
\hline & Interval & Interval & \\
\hline $\begin{array}{l}\text { NDM Rank, Area } 1 \text { Most Important, } \\
2007\end{array}$ & {$[4.08,26.39]$} & {$[0.59,0.91]$} & 0.566 \\
\hline $\begin{array}{c}\text { NDM Rank, Area } 2 \text { Most Important, } \\
2007\end{array}$ & {$[-2.28,7.30]$} & {$[0.89,1.03]$} & 0.920 \\
\hline $\begin{array}{c}\text { NDM Rank, Area } 3 \text { Most Important, } \\
2007\end{array}$ & {$[-2.27,7.49]$} & {$[0.89,1.03]$} & 0.917 \\
\hline $\begin{array}{c}\text { NDM Rank, Area } 4 \text { Most Important, } \\
2007\end{array}$ & {$[-2.03,9.83]$} & {$[0.85,1.02]$} & 0.877 \\
\hline $\begin{array}{c}\text { NDM Rank, Area } 5 \text { Most Important, } \\
2007\end{array}$ & {$[-1.89,10.70]$} & {$[0.84,1.02]$} & 0.862 \\
\hline
\end{tabular}


Figure 1

Regression Line Where NDM Rank Most Important, 2007

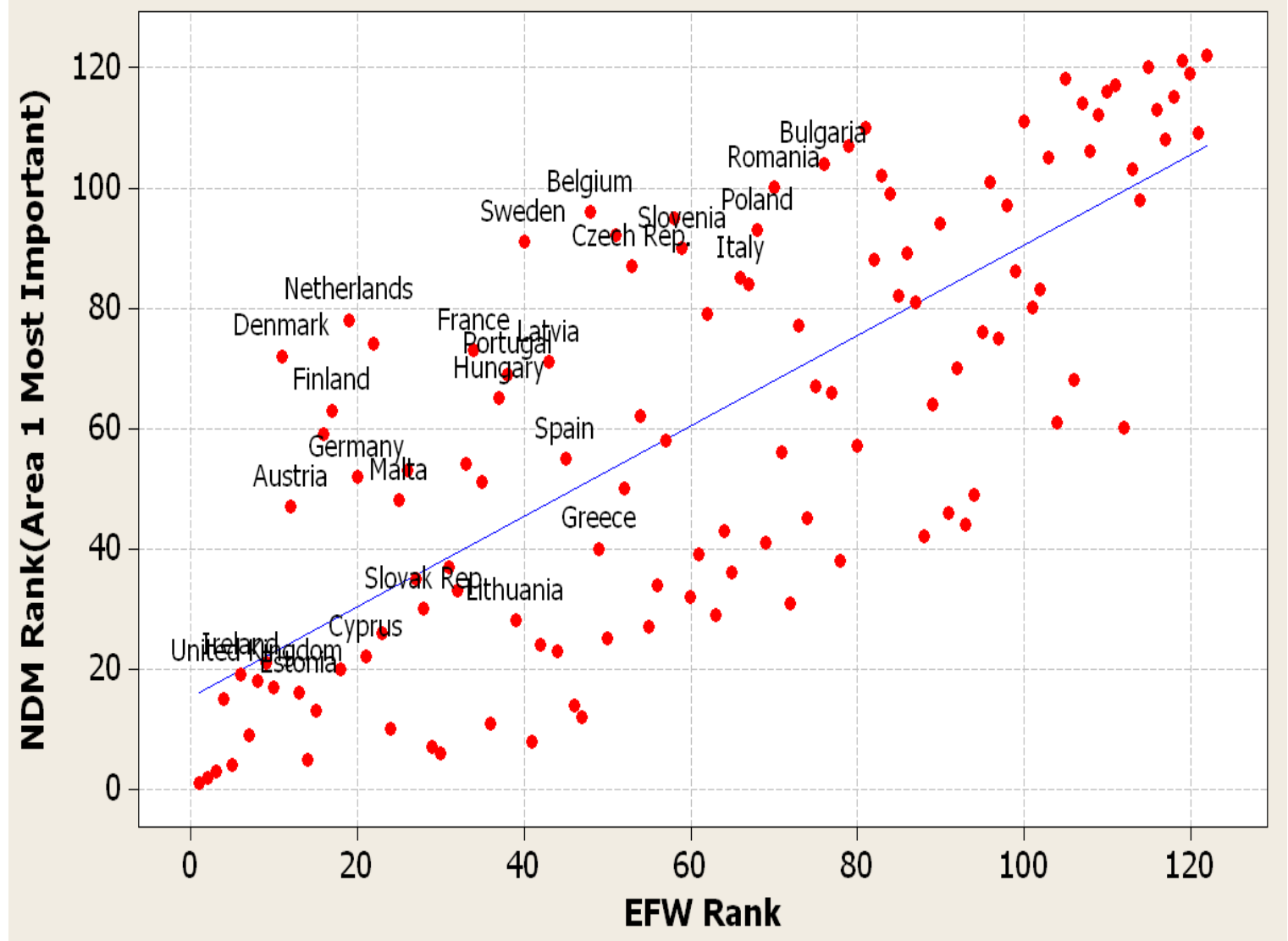


Figure 2

\section{European Countries in the World Top 20 in Real GDP/capita}

Vertical Axis: NDM Economic Freedom Rank

Horizontal Axis: Area Assumed Most Important for Economic Freedom

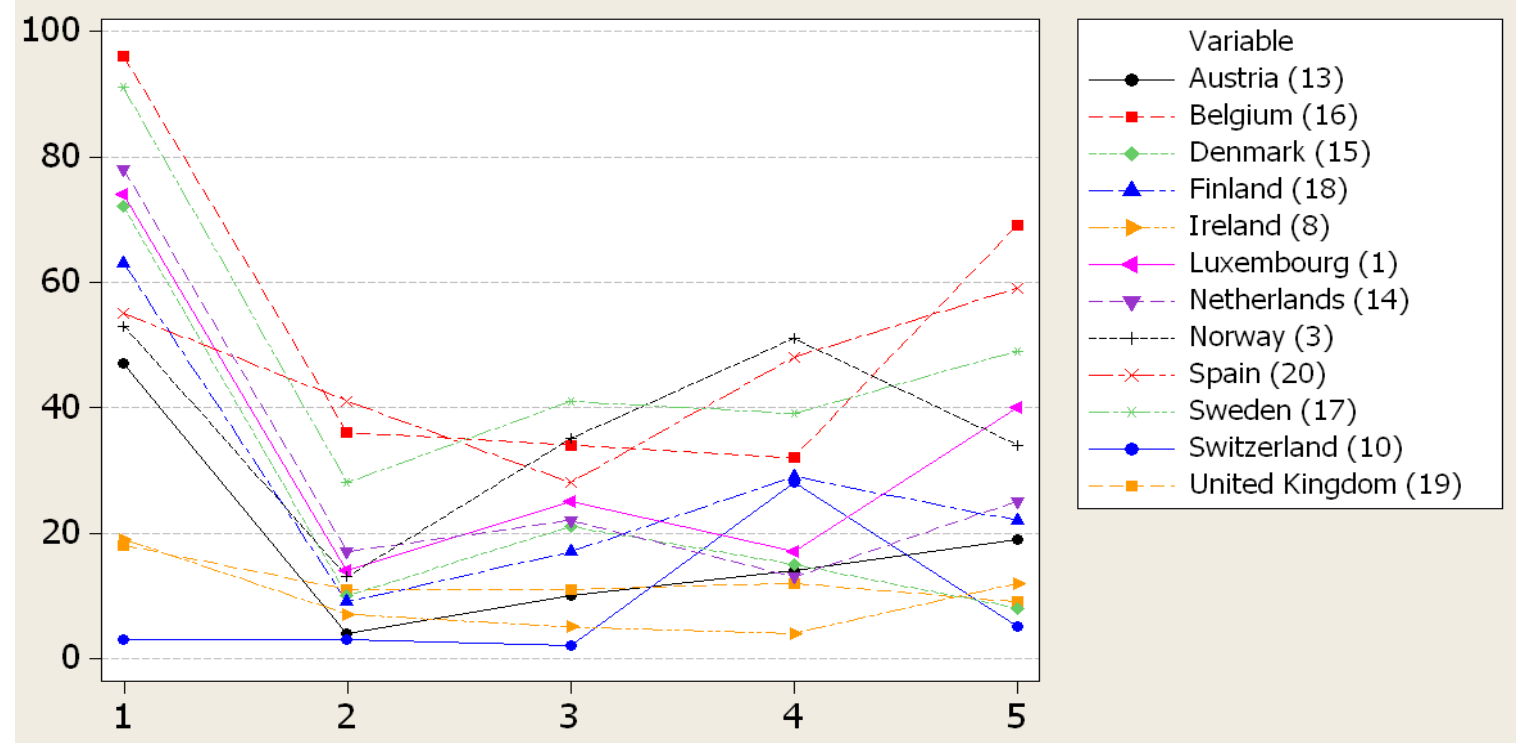

Note: Each country's world rank in GDP per capita in 2007 shown in parentheses. 
Appendix Table A1

Country Rankings When Area 1 (Size of Government) Is Most Important

\begin{tabular}{|c|c|c|c|c|c|c|c|c|}
\hline Rank & Country & $\begin{array}{l}\text { Avg. } \\
\text { NDM }\end{array}$ & Rank & Country & $\begin{array}{l}\text { Avg. } \\
\text { NDM }\end{array}$ & Rank & Country & $\begin{array}{l}\text { Avg. } \\
\text { NDM }\end{array}$ \\
\hline 1 & Hong Kong & 119.0 & 42 & Haiti & 20.8 & 83 & Cameroon & -19.5 \\
\hline 2 & Singapore & 104.4 & 43 & Egypt & 20.8 & 84 & Namibia & -23.0 \\
\hline 3 & Switzerland & 97.6 & 44 & Cote d'Ivoire & 20.2 & 85 & Italy & -25.6 \\
\hline 4 & Chile & 95.2 & 45 & Nicaragua & 18.4 & 86 & Sri Lanka & -26.9 \\
\hline 5 & Mauritius & 86.1 & 46 & Madagascar & 18.0 & 87 & Czech Rep. & -27.5 \\
\hline 6 & El Salvador & 78.3 & 47 & Austria & 17.6 & 88 & Nigeria & -29.5 \\
\hline 7 & Panama & 75.8 & 48 & Malta & 15.5 & 89 & Iran & -30.2 \\
\hline 8 & Albania & 74.3 & 49 & Sierra Leone & 13.7 & 90 & Slovenia & -35.2 \\
\hline 9 & United States & 71.3 & 50 & Belize & 13.5 & 91 & Sweden & -35.3 \\
\hline 10 & Costa Rica & 69.8 & 51 & Japan & 12.7 & 92 & Israel & -35.4 \\
\hline 11 & Guatemala & 69.5 & 52 & Germany & 12.1 & 93 & Poland & -35.5 \\
\hline 12 & Jamaica & 68.4 & 53 & Norway & 12.1 & 94 & Bolivia & -35.9 \\
\hline 13 & Taiwan & 65.3 & 54 & Jordan & 12.0 & 95 & Botswana & -36.7 \\
\hline 14 & Honduras & 63.1 & 55 & Spain & 11.2 & 96 & Belgium & -37.6 \\
\hline 15 & New Zealand & 60.7 & 56 & Uganda & 10.4 & 97 & Gabon & -44.3 \\
\hline 16 & Estonia & 60.6 & 57 & Mali & 10.4 & 98 & Chad & -45.7 \\
\hline 17 & Australia & 58.1 & 58 & Barbados & 10.0 & 99 & Tanzania & -46.5 \\
\hline 18 & U.K. & 55.4 & 59 & Oman & 9.9 & 100 & Romania & -47.6 \\
\hline 19 & Ireland & 54.5 & 60 & Togo & 8.6 & 101 & Brazil & -48.0 \\
\hline 20 & Unit. Arab Em. & 53.1 & 61 & Bangladesh & 6.2 & 102 & Tunisia & -56.0 \\
\hline 21 & Canada & 52.0 & 62 & Ghana & 4.8 & 103 & Nepal & -56.5 \\
\hline 22 & Cyprus & 51.5 & 63 & Finland & 4.2 & 104 & Bulgaria & -56.8 \\
\hline 23 & Zambia & 50.2 & 64 & Dom. Rep. & 4.0 & 105 & Syria & -59.0 \\
\hline 24 & Bahamas & 49.1 & 65 & Hungary & 3.9 & 106 & Senegal & -62.6 \\
\hline 25 & Peru & 43.5 & 66 & Indonesia & 3.3 & 107 & China & -63.5 \\
\hline 26 & Iceland & 39.5 & 67 & India & 2.8 & 108 & Cen. Afr. Rep. & -68.3 \\
\hline 27 & Trinidad \& Tob. & 34.4 & 68 & Ecuador & 2.2 & 109 & Myanmar & -69.2 \\
\hline 28 & Lithuania & 32.8 & 69 & Portugal & 2.0 & 110 & Croatia & -69.6 \\
\hline 29 & Kenya & 31.8 & 70 & Paraguay & -1.1 & 111 & Malawi & -71.8 \\
\hline 30 & Slovak Rep & 31.3 & 71 & Latvia & -1.4 & 112 & Ukraine & -73.4 \\
\hline 31 & Philippines & 30.8 & 72 & Denmark & -1.7 & 113 & Congo, D. R. & -82.3 \\
\hline 32 & Uruguay & 28.7 & 73 & France & -3.4 & 114 & Colombia & -90.5 \\
\hline 33 & Korea & 28.5 & 74 & Luxembourg & -3.4 & 115 & Niger & -90.9 \\
\hline 34 & South Africa & 28.4 & 75 & Argentina & -4.2 & 116 & Burundi & -93.5 \\
\hline 35 & Kuwait & 27.2 & 76 & Benin & -5.7 & 117 & Algeria & -94.0 \\
\hline 36 & Mexico & 25.3 & 77 & Pap. N. Guinea & -9.0 & 118 & Guyana & -101.3 \\
\hline 37 & Bahrain & 25.0 & 78 & Netherlands & -13.2 & 119 & Venezuela & -107.8 \\
\hline 38 & Turkey & 24.0 & 79 & Malaysia & -13.6 & 120 & Guinea-Bissau & -113.4 \\
\hline 39 & Thailand & 23.5 & 80 & Pakistan & -16.5 & 121 & Congo, Rep. Of & -114.0 \\
\hline 40 & Greece & 23.0 & 81 & Morocco & -17.0 & 122 & Zimbabwe & -115.3 \\
\hline 41 & Fiji & 22.8 & 82 & Russia & -19.2 & & & \\
\hline
\end{tabular}

Note: Area 1 is held constant in the first position of all importance orderings. Here, therefore, are the average NDM results in 2007 for the following 24 importance orderings: $(1,2,3,4,5),(1,2,3,5,4),(1,2,4,3,5),(1,2,4,5,3),(1,2,5,3,4),(1,2,5,4,3),(1,3,2,4,5)$,

$(1,3,2,5,4),(1,3,4,2,5),(1,3,4,5,2),(1,3,5,2,4),(1,3,5,4,2),(1,4,2,3,5),(1,4,2,5,3),(1,4,3,2,5),(1,4,3,5,2),(1,4,5,2,3),(1,4,5,3,2)$, $(1,5,2,3,4),(1,5,2,4,3),(1,5,3,2,4),(1,5,3,4,2),(1,5,4,2,3)$, and $(1,5,4,3,2)$. 
Appendix Table A2

Country Rankings When Area 2 (Legal Structure and Property Rights) Is Most Important

\begin{tabular}{|c|c|c|c|c|c|c|c|c|}
\hline Rank & Country & $\begin{array}{l}\text { Avg. } \\
\text { NDM }\end{array}$ & Rank & Country & $\begin{array}{l}\text { Avg. } \\
\text { NDM }\end{array}$ & Rank & Country & $\begin{array}{l}\text { Avg. } \\
\text { NDM }\end{array}$ \\
\hline 1 & New Zealand & 108.6 & 42 & Latvia & 27.5 & 83 & Mali & -38.9 \\
\hline 2 & Hong Kong & 106.5 & 43 & Botswana & 26.6 & 84 & Russia & -39.0 \\
\hline 3 & Switzerland & 105.1 & 44 & South Africa & 26.5 & 85 & Indonesia & -43.0 \\
\hline 4 & Austria & 103.8 & 45 & Lithuania & 24.3 & 86 & Malawi & -44.0 \\
\hline 5 & Australia & 103.4 & 46 & Fiji & 23.9 & 87 & Uganda & -47.5 \\
\hline 6 & Singapore & 102.8 & 47 & Malaysia & 23.5 & 88 & Syria & -50.6 \\
\hline 7 & Ireland & 102.1 & 48 & Greece & 23.1 & 89 & Benin & -52.3 \\
\hline 8 & Canada & 100.5 & 49 & Belize & 22.3 & 90 & Brazil & -52.8 \\
\hline 9 & Finland & 99.7 & 50 & Slovenia & 21.1 & 91 & Gabon & -52.9 \\
\hline 10 & Denmark & 98.9 & 51 & Zambia & 20.7 & 92 & Dom. Rep. & -54.0 \\
\hline 11 & U.K. & 97.7 & 52 & Panama & 18.6 & 93 & Nicaragua & -55.3 \\
\hline 12 & Germany & 91.8 & 53 & Israel & 18.4 & 94 & Sri Lanka & -59.8 \\
\hline 13 & Norway & 90.9 & 54 & Jamaica & 16.3 & 95 & Sierra Leone & -65.0 \\
\hline 14 & Luxembourg & 89.0 & 55 & Ghana & 15.6 & 96 & Ukraine & -67.4 \\
\hline 15 & Iceland & 88.7 & 56 & Guatemala & 14.5 & 97 & Cote d'Ivoire & -67.9 \\
\hline 16 & United States & 84.5 & 57 & Czech Rep. & 9.5 & 98 & Argentina & -69.1 \\
\hline 17 & Netherlands & 83.7 & 58 & Egypt & 7.9 & 99 & Bolivia & -73.2 \\
\hline 18 & Mauritius & 78.6 & 59 & Uruguay & 7.3 & 100 & Guyana & -73.2 \\
\hline 19 & Oman & 78.3 & 60 & Thailand & 5.1 & 101 & Madagascar & -73.7 \\
\hline 20 & Cyprus & 78.2 & 61 & India & 4.0 & 102 & Algeria & -76.0 \\
\hline 21 & Chile & 77.3 & 62 & Trinidad \& Tob. & 1.8 & 103 & Senegal & -77.6 \\
\hline 22 & Estonia & 76.2 & 63 & Poland & -0.3 & 104 & Cameroon & -79.3 \\
\hline 23 & Malta & 73.5 & 64 & Tunisia & -2.6 & 105 & Pakistan & -79.6 \\
\hline 24 & Unit. Arab Em. & 70.1 & 65 & Albania & -2.7 & 106 & Colombia & -82.8 \\
\hline 25 & Costa Rica & 65.1 & 66 & Italy & -3.3 & 107 & Paraguay & -82.9 \\
\hline 26 & Kuwait & 64.9 & 67 & El Salvador & -3.9 & 108 & Haiti & -83.5 \\
\hline 27 & France & 63.7 & 68 & Peru & -9.8 & 109 & Guinea-Bissau & -87.8 \\
\hline 28 & Sweden & 60.0 & 69 & Mexico & -11.3 & 110 & Bangladesh & -87.8 \\
\hline 29 & Japan & 58.8 & 70 & Honduras & -12.9 & 111 & Ecuador & -88.7 \\
\hline 30 & Taiwan & 58.8 & 71 & Romania & -17.0 & 112 & Niger & -91.5 \\
\hline 31 & Bahamas & 57.3 & 72 & Tanzania & -18.8 & 113 & Togo & -92.5 \\
\hline 32 & Portugal & 53.0 & 73 & Turkey & -20.0 & 114 & Burundi & -95.8 \\
\hline 33 & Korea & 50.5 & 74 & Kenya & -21.2 & 115 & Myanmar & -104.4 \\
\hline 34 & Hungary & 47.0 & 75 & Croatia & -22.3 & 116 & Cen. Afr. Rep. & -106.3 \\
\hline 35 & Barbados & 44.0 & 76 & Iran & -23.3 & 117 & Nepal & -108.0 \\
\hline 36 & Belgium & 42.2 & 77 & Morocco & -24.8 & 118 & Chad & -108.3 \\
\hline 37 & Slovak Rep & 41.3 & 78 & Pap. New Guinea & -26.0 & 119 & Congo, Dem. R. & -109.3 \\
\hline 38 & Bahrain & 40.9 & 79 & China & -26.9 & 120 & Zimbabwe & -110.4 \\
\hline 39 & Jordan & 40.6 & 80 & Nigeria & -29.8 & 121 & Congo, Rep. Of & -110.8 \\
\hline 40 & Namibia & 35.9 & 81 & Philippines & -32.8 & 122 & Venezuela & -115.3 \\
\hline 41 & Spain & 33.3 & 82 & Bulgaria & -37.7 & & & \\
\hline
\end{tabular}

Note: Area 2 is held constant in the first position of all importance orderings. Here, therefore, are the average NDM results in 2007 for the following 24 importance orderings: $(2,1,3,4,5),(2,1,3,5,4),(2,1,4,3,5),(2,1,4,5,3),(2,1,5,3,4),(2,1,5,4,3),(2,3,1,4,5)$,

$(2,3,1,5,4),(2,3,4,1,5),(2,3,4,5,1),(2,3,5,1,4),(2,3,5,4,1),(2,4,1,3,5),(2,4,1,5,3),(2,4,3,1,5),(2,4,3,5,1),(2,4,5,1,3),(2,4,5,3,1)$, $(2,5,1,3,4),(2,5,1,4,3),(2,5,3,1,4),(2,5,3,4,1),(2,5,4,1,3)$, and $(2,5,4,3,1)$. 
Appendix Table A3

Country Rankings When Area 3 (Sound Money) Is Most Important

\begin{tabular}{|c|c|c|c|c|c|c|c|c|}
\hline Rank & Country & $\begin{array}{l}\text { Avg. } \\
\text { NDM }\end{array}$ & Rank & Country & $\begin{array}{l}\text { Avg. } \\
\text { NDM }\end{array}$ & Rank & Country & $\begin{array}{l}\text { Avg. } \\
\text { NDM }\end{array}$ \\
\hline 1 & New Zealand & 106.4 & 42 & Peru & 37.5 & 83 & Namibia & -41.5 \\
\hline 2 & Switzerland & 103.2 & 43 & Czech Rep. & 37.0 & 84 & Tanzania & -42.3 \\
\hline 3 & Hong Kong & 101.5 & 44 & Italy & 36.9 & 85 & Madagascar & -43.7 \\
\hline 4 & United States & 99.8 & 45 & Lithuania & 35.8 & 86 & Burundi & -44.1 \\
\hline 5 & Ireland & 98.8 & 46 & Honduras & 35.3 & 87 & Fiji & -46.1 \\
\hline 6 & Taiwan & 94.5 & 47 & Unit. Arab Em. & 35.0 & 88 & Sierra Leone & -46.5 \\
\hline 7 & Singapore & 92.0 & 48 & Israel & 34.7 & 89 & Tunisia & -51.0 \\
\hline 8 & Canada & 81.5 & 49 & Iceland & 30.8 & 90 & India & -51.2 \\
\hline 9 & Australia & 80.3 & 50 & Latvia & 28.1 & 91 & Brazil & -53.1 \\
\hline 10 & Austria & 80.0 & 51 & Zambia & 26.4 & 92 & Syria & -55.3 \\
\hline 11 & U.K. & 78.5 & 52 & Slovenia & 23.3 & 93 & Turkey & -55.5 \\
\hline 12 & Korea & 74.3 & 53 & Trinidad \& Tob. & 20.8 & 94 & Argentina & -55.5 \\
\hline 13 & Chile & 72.5 & 54 & Uganda & 20.8 & 95 & Morocco & -57.5 \\
\hline 14 & Malta & 71.9 & 55 & Jamaica & 19.8 & 96 & Nigeria & -57.9 \\
\hline 15 & Estonia & 70.6 & 56 & Kenya & 18.6 & 97 & Colombia & -60.0 \\
\hline 16 & Japan & 70.5 & 57 & Poland & 15.8 & 98 & Benin & -61.0 \\
\hline 17 & Finland & 70.2 & 58 & Botswana & 14.8 & 99 & Guyana & -61.3 \\
\hline 18 & Cyprus & 70.1 & 59 & Belize & 12.2 & 100 & Cote d'Ivoire & -61.6 \\
\hline 19 & Mauritius & 69.8 & 60 & Egypt & 9.2 & 101 & Togo & -64.3 \\
\hline 20 & Germany & 67.7 & 61 & China & 7.8 & 102 & Cameroon & -65.3 \\
\hline 21 & Denmark & 67.7 & 62 & Ghana & 5.1 & 103 & Malawi & -69.4 \\
\hline 22 & Netherlands & 67.3 & 63 & Nicaragua & 3.5 & 104 & Dom. Rep. & -74.0 \\
\hline 23 & France & 65.7 & 64 & Romania & 2.5 & 105 & Congo, Dem. R. & -76.3 \\
\hline 24 & Portugal & 60.9 & 65 & Uruguay & -0.4 & 106 & Bangladesh & -78.3 \\
\hline 25 & Luxembourg & 60.8 & 66 & South Africa & -5.5 & 107 & Pakistan & -79.1 \\
\hline 26 & Panama & 60.3 & 67 & Mexico & -6.2 & 108 & Senegal & -79.4 \\
\hline 27 & Slovak Rep & 60.1 & 68 & Philippines & -7.7 & 109 & Nepal & -80.2 \\
\hline 28 & Spain & 59.1 & 69 & Bahamas & -10.8 & 110 & Gabon & -81.5 \\
\hline 29 & Greece & 58.9 & 70 & Haiti & -13.1 & 111 & Sri Lanka & -82.8 \\
\hline 30 & El Salvador & 58.3 & 71 & Bulgaria & -14.3 & 112 & Cen. Afr. Rep. & -84.3 \\
\hline 31 & Oman & 56.0 & 72 & Russia & -23.3 & 113 & Niger & -93.3 \\
\hline 32 & Guatemala & 55.4 & 73 & Thailand & -24.3 & 114 & Algeria & -93.6 \\
\hline 33 & Albania & 50.0 & 74 & Croatia & -27.2 & 115 & Ecuador & -96.9 \\
\hline 34 & Belgium & 50.0 & 75 & Paraguay & -27.2 & 116 & Ukraine & -102.1 \\
\hline 35 & Norway & 49.5 & 76 & Barbados & -30.6 & 117 & Guinea-Bissau & -102.8 \\
\hline 36 & Costa Rica & 49.0 & 77 & Bolivia & -31.4 & 118 & Chad & -103.1 \\
\hline 37 & Jordan & 48.7 & 78 & Indonesia & -33.0 & 119 & Congo, Rep. Of & -111.5 \\
\hline 38 & Bahrain & 46.2 & 79 & Pap. New Guinea & -35.9 & 120 & Venezuela & -113.4 \\
\hline 39 & Kuwait & 46.0 & 80 & Malaysia & -36.0 & 121 & Myanmar & -117.7 \\
\hline 40 & Hungary & 42.1 & 81 & Iran & -38.0 & 122 & Zimbabwe & -121.0 \\
\hline 41 & Sweden & 41.6 & 82 & Mali & -39.3 & & & \\
\hline
\end{tabular}

Note: Area 3 is held constant in the first position of all importance orderings. Here, therefore, are the average NDM results in 2007 for the following 24 importance orderings: $(3,1,2,4,5),(3,1,2,5,4),(3,1,4,2,5),(3,1,4,5,2),(3,1,5,2,4),(3,1,5,4,2),(3,2,1,4,5)$,

$(3,2,1,5,4),(3,2,4,1,5),(3,2,4,5,1),(3,2,5,1,4),(3,2,5,4,1),(3,4,1,2,5),(3,4,1,5,2),(3,4,2,1,5),(3,4,2,5,1),(3,4,5,1,2),(3,4,5,2,1)$, $(3,5,1,2,4),(3,5,1,4,2),(3,5,2,1,4),(3,5,2,4,1),(3,5,4,1,2)$, and $(3,5,4,2,1)$. 
Appendix Table A4

Country Rankings When Area 4 (Freedom to Trade Internationally) Is Most Important

\begin{tabular}{|c|c|c|c|c|c|c|c|c|}
\hline Rank & Country & $\begin{array}{c}\text { Avg. } \\
\text { NDM }\end{array}$ & Rank & Country & $\begin{array}{c}\text { Avg. } \\
\text { NDM }\end{array}$ & Rank & Country & $\begin{array}{c}\text { Avg. } \\
\text { NDM }\end{array}$ \\
\hline 1 & Hong Kong & 121.0 & 42 & Korea & 35.9 & 83 & Croatia & -30.1 \\
\hline 2 & Singapore & 119.0 & 43 & Thailand & 33.5 & 84 & Madagascar & -30.3 \\
\hline 3 & Chile & 105.5 & 44 & Pap. New Guinea & 33.1 & 85 & Mali & -31.2 \\
\hline 4 & Ireland & 105.2 & 45 & Ghana & 32.9 & 86 & Haiti & -32.7 \\
\hline 5 & Estonia & 93.7 & 46 & Portugal & 30.7 & 87 & Barbados & -35.7 \\
\hline 6 & New Zealand & 90.1 & 47 & Kuwait & 28.8 & 88 & Fiji & -38.9 \\
\hline 7 & Unit. Arab Em. & 87.0 & 48 & Spain & 22.3 & 89 & Tunisia & -43.2 \\
\hline 8 & Slovak Rep & 84.3 & 49 & Jamaica & 21.5 & 90 & Argentina & -48.0 \\
\hline 9 & Taiwan & 81.4 & 50 & Malaysia & 20.2 & 91 & Ecuador & -49.0 \\
\hline 10 & United States & 80.8 & 51 & Norway & 18.2 & 92 & Tanzania & -53.0 \\
\hline 11 & Panama & 76.5 & 52 & Bulgaria & 18.0 & 93 & Cote d'Ivoire & -53.5 \\
\hline 12 & U.K. & 73.6 & 53 & Romania & 14.5 & 94 & Brazil & -53.5 \\
\hline 13 & Netherlands & 69.4 & 54 & Uruguay & 10.3 & 95 & Morocco & -54.3 \\
\hline 14 & Austria & 69.0 & 55 & Trinidad \& Tob. & 9.6 & 96 & Sri Lanka & -55.2 \\
\hline 15 & Denmark & 68.8 & 56 & Slovenia & 8.4 & 97 & Russia & -55.3 \\
\hline 16 & Mauritius & 68.7 & 57 & Nicaragua & 5.4 & 98 & Togo & -57.8 \\
\hline 17 & Luxembourg & 66.8 & 58 & Italy & 4.0 & 99 & Bangladesh & -62.6 \\
\hline 18 & Bahrain & 66.1 & 59 & South Africa & 3.0 & 100 & Pakistan & -66.0 \\
\hline 19 & Germany & 64.8 & 60 & Albania & 2.9 & 101 & Ukraine & -66.8 \\
\hline 20 & Costa Rica & 64.8 & 61 & Mexico & 1.8 & 102 & Gabon & -69.6 \\
\hline 21 & Oman & 63.4 & 62 & Iceland & 1.5 & 103 & Iran & -73.3 \\
\hline 22 & Hungary & 62.5 & 63 & Botswana & 0.8 & 104 & Sierra Leone & -74.0 \\
\hline 23 & Jordan & 56.2 & 64 & Japan & 0.6 & 105 & Colombia & -74.5 \\
\hline 24 & Malta & 54.8 & 65 & Philippines & 0.5 & 106 & Senegal & -75.4 \\
\hline 25 & Canada & 53.8 & 66 & Greece & -0.3 & 107 & Benin & -75.5 \\
\hline 26 & Honduras & 53.4 & 67 & Kenya & -0.7 & 108 & Algeria & -75.9 \\
\hline 27 & Cyprus & 53.2 & 68 & China & -2.7 & 109 & Syria & -76.0 \\
\hline 28 & Switzerland & 51.4 & 69 & Egypt & -3.3 & 110 & Malawi & -78.2 \\
\hline 29 & Finland & 50.6 & 70 & Nigeria & -4.5 & 111 & Cameroon & -79.5 \\
\hline 30 & Guatemala & 45.3 & 71 & Poland & -5.4 & 112 & Niger & -82.0 \\
\hline 31 & Czech Rep. & 44.3 & 72 & Indonesia & -5.5 & 113 & Chad & -90.5 \\
\hline 32 & Belgium & 43.0 & 73 & Paraguay & -9.2 & 114 & Guinea-Bissau & -93.0 \\
\hline 33 & Israel & 42.8 & 74 & Namibia & -10.1 & 115 & Congo, Dem. R. & -93.8 \\
\hline 34 & Australia & 42.6 & 75 & Uganda & -12.0 & 116 & Nepal & -94.3 \\
\hline 35 & El Salvador & 42.0 & 76 & Dom. Rep. & -17.1 & 117 & Burundi & -99.9 \\
\hline 36 & Lithuania & 41.1 & 77 & Guyana & -17.6 & 118 & Congo, Rep. Of & -102.0 \\
\hline 37 & France & 40.5 & 78 & India & -19.0 & 119 & Cen. Afr. Rep. & -113.1 \\
\hline 38 & Peru & 37.9 & 79 & Turkey & -22.6 & 120 & Venezuela & -114.5 \\
\hline 39 & Sweden & 37.3 & 80 & Bahamas & -25.4 & 121 & Myanmar & -119.7 \\
\hline 40 & Zambia & 37.0 & 81 & Bolivia & -26.8 & 122 & Zimbabwe & -120.0 \\
\hline 41 & Latvia & 36.1 & 82 & Belize & -30.1 & & & \\
\hline
\end{tabular}

Note: Area 4 is held constant in the first position of all importance orderings. Here, therefore, are the average NDM results in 2007 for the following 24 importance orderings: $(4,1,2,3,5),(4,1,2,5,3),(4,1,3,2,5),(4,1,3,5,2),(4,1,5,2,3),(4,1,5,3,2),(4,2,1,3,5)$, $(4,2,1,5,3),(4,2,3,1,5),(4,2,3,5,1),(4,2,5,1,3),(4,2,5,3,1),(4,3,1,2,5),(4,3,1,5,2),(4,3,2,1,5),(4,3,2,5,1),(4,3,5,1,2),(4,3,5,2,1)$, $(4,5,1,2,3),(4,5,1,3,2),(4,5,2,1,3),(4,5,2,3,1),(4,5,3,1,2)$, and $(4,5,3,2,1)$. 
Appendix Table A5

Country Rankings When Area 5 (Regulation) Is Most Important

\begin{tabular}{|c|c|c|c|c|c|c|c|c|}
\hline Rank & Country & $\begin{array}{c}\text { Avg. } \\
\text { NDM }\end{array}$ & Rank & Country & $\begin{array}{c}\text { Avg. } \\
\text { NDM }\end{array}$ & Rank & Country & $\begin{array}{c}\text { Avg. } \\
\text { NDM }\end{array}$ \\
\hline 1 & Singapore & 113.8 & 42 & Malaysia & 26.5 & 83 & Haiti & -28.8 \\
\hline 2 & Hong Kong & 113.1 & 43 & Uganda & 26.1 & 84 & Indonesia & -29.3 \\
\hline 3 & New Zealand & 106.7 & 44 & Namibia & 24.1 & 85 & Philippines & -31.3 \\
\hline 4 & Chile & 103.5 & 45 & Thailand & 23.1 & 86 & Italy & -31.5 \\
\hline 5 & Switzerland & 100.5 & 46 & Zambia & 21.4 & 87 & Egypt & -37.0 \\
\hline 6 & United States & 98.3 & 47 & Germany & 20.9 & 88 & India & -40.8 \\
\hline 7 & Oman & 91.3 & 48 & Costa Rica & 19.8 & 89 & Cote d'Ivoire & -41.8 \\
\hline 8 & Denmark & 89.5 & 49 & Sweden & 19.5 & 90 & Tanzania & -46.6 \\
\hline 9 & United Kingdom & 86.3 & 50 & Israel & 18.8 & 91 & Bolivia & -52.2 \\
\hline 10 & Canada & 83.9 & 51 & Mexico & 17.6 & 92 & Benin & -52.2 \\
\hline 11 & Estonia & 81.3 & 52 & Pap. New Guinea & 15.0 & 93 & Dom. Rep. & -52.2 \\
\hline 12 & Ireland & 77.6 & 53 & Mali & 13.3 & 94 & Madagascar & -52.9 \\
\hline 13 & Unit. Arab Em. & 76.8 & 54 & Portugal & 12.3 & 95 & Guyana & -53.4 \\
\hline 14 & Australia & 73.5 & 55 & Jamaica & 11.2 & 96 & Malawi & -53.4 \\
\hline 15 & Taiwan & 72.2 & 56 & France & 10.2 & 97 & Paraguay & -56.7 \\
\hline 16 & Kuwait & 68.2 & 57 & Peru & 9.8 & 98 & Morocco & -56.9 \\
\hline 17 & Iceland & 67.6 & 58 & South Africa & 9.6 & 99 & China & -57.2 \\
\hline 18 & Belize & 62.6 & 59 & Spain & 8.8 & 100 & Sri Lanka & -57.3 \\
\hline 19 & Austria & 62.4 & 60 & Trinidad \& Tob. & 8.4 & 101 & Russia & -58.7 \\
\hline 20 & El Salvador & 60.8 & 61 & Romania & 7.2 & 102 & Guinea-Bissau & -60.0 \\
\hline 21 & Mauritius & 54.5 & 62 & Czech Rep. & 6.8 & 103 & Iran & -60.2 \\
\hline 22 & Finland & 53.7 & 63 & Botswana & 6.5 & 104 & Bangladesh & -64.1 \\
\hline 23 & Bahrain & 53.5 & 64 & Ghana & 5.2 & 105 & Cameroon & -64.6 \\
\hline 24 & Bahamas & 53.0 & 65 & Gabon & 4.9 & 106 & Brazil & -68.3 \\
\hline 25 & Netherlands & 52.7 & 66 & Nicaragua & 3.2 & 107 & Ecuador & -70.0 \\
\hline 26 & Jordan & 51.9 & 67 & Kenya & 2.5 & 108 & Argentina & -70.5 \\
\hline 27 & Latvia & 48.9 & 68 & Honduras & 2.2 & 109 & Congo, Rep. Of & -70.9 \\
\hline 28 & Barbados & 47.1 & 69 & Belgium & -2.0 & 110 & Colombia & -72.6 \\
\hline 29 & Lithuania & 45.0 & 70 & Burundi & -3.9 & 111 & Ukraine & -82.6 \\
\hline 30 & Guatemala & 40.8 & 71 & Bulgaria & -5.8 & 112 & Syria & -91.2 \\
\hline 31 & Slovak Rep & 39.5 & 72 & Sierra Leone & -6.7 & 113 & Senegal & -93.5 \\
\hline 32 & Korea & 37.1 & 73 & Greece & -8.5 & 114 & Algeria & -95.2 \\
\hline 33 & Japan & 36.9 & 74 & Slovenia & -9.1 & 115 & Chad & -102.5 \\
\hline 34 & Norway & 35.2 & 75 & Croatia & -9.3 & 116 & Togo & -103.9 \\
\hline 35 & Cyprus & 34.7 & 76 & Uruguay & -10.5 & 117 & Cen. Afr. Rep. & -109.1 \\
\hline 36 & Fiji & 34.3 & 77 & Nigeria & -16.4 & 118 & Congo, Dem. R. & -109.9 \\
\hline 37 & Malta & 32.6 & 78 & Turkey & -17.1 & 119 & Venezuela & -111.2 \\
\hline 38 & Panama & 32.4 & 79 & Pakistan & -17.8 & 120 & Myanmar & -114.0 \\
\hline 39 & Albania & 29.8 & 80 & Tunisia & -18.3 & 121 & Niger & -114.9 \\
\hline 40 & Luxembourg & 27.6 & 81 & Poland & -21.8 & 122 & Zimbabwe & -118.4 \\
\hline 41 & Hungary & 27.0 & 82 & Nepal & -27.5 & & & \\
\hline
\end{tabular}

Note: Area 5 is held constant in the first position of all importance orderings. Here, therefore, are the average NDM results in 2007 for the following 24 importance orderings: $(5,1,2,3,4),(5,1,2,4,3),(5,1,3,2,4),(5,1,3,4,2),(5,1,4,2,3),(5,1,4,3,2),(5,2,1,3,4)$, $(5,2,1,4,3),(5,2,3,1,4),(5,2,3,4,1),(5,2,4,1,3),(5,2,4,3,1),(5,3,1,2,4),(5,3,1,4,2),(5,3,2,1,4),(5,3,2,4,1),(5,3,4,1,2),(5,3,4,2,1)$, $(5,4,1,2,3),(5,4,1,3,2),(5,4,2,1,3),(5,4,2,3,1),(5,4,3,1,2)$, and $(5,4,3,2,1)$. 


\section{References}

Beaulier, S., and R. Elder (2011), 'Employing the 'Dominetrics to Impose Greater Discipline on Performance Rankings', Journal of Sports Economics 12(1): 55-80.

Bologna, J. and J. Hall (2014), 'Economic Freedom Research: Some Comments and Suggestions,' in J. Hall (ed.), Economic Freedom and Economic Education, Ideas and Influence of James Gwartney, Beloit, WI: Beloit College Press.

Caudill, S., Zanella, F., and F. Mixon (2000), 'Is Economic Freedom One Dimensional? A Factor Analysis of Some Common Measures of Economic Freedom', Journal of Economic Development 25(1): 17-40.

Cherchye, L. and F. Vermeulen (2006), 'Robust Rankings of Multidimensional Performances,' Journal of Sports Economics, 7(4): 359-373.

Gwartney, J. and R. Lawson (2000), 'Developing a Measure of Economic Freedom', in W. Rushing (ed.) The Visible Hand: The Challenge to Private Enterprise in the 21st Century, East Lansing, MI: Michigan State University Press.

Gwartney, J. R. Lawson, and J. Hall (2009). Economic Freedom of the World: 2009 Annual Report, Vancouver, Canada: Fraser Institute.

Gwartney, J. R. Lawson, and J. Hall (2014). Economic Freedom of the World: 2014 Annual Report, Vancouver, Canada: Fraser Institute.

Hall, J. and R. Lawson (2014), 'Economic Freedom of the World: An Accounting of the Literature', Contemporary Economic Policy 32(1): 1-19.

Hall, J. and D. Yu (2012), 'Ranking the Economic Freedom of North America using Dominetrics', Economics Bulletin 32(3): 1949-1961.

Heckelman, J. and M. Stroup (2000), 'Which Economic Freedoms Contribute to 
Growth?', Kyklos 53(4): 527-544.

Huskinson, T. and R. Lawson (2015), 'Clusters of Economic Freedom', Applied Economics Letters 21(15): 1070-1074.

Kunčič, A. (2014), 'Institutional Quality Dataset', Journal of Institutional Economics 10(1): $135-161$.

Lawson, R. (2008). 'On the Methodology of the Economic Freedom of the World Index', K. Banaian and B. Roberts (eds.), The Design and Use of Political Economy Indicators, New York: Palgrave Macmillan.

Robinson, J.A. (2013), 'Measuring Institutions in the Tobriand Islands: A Comment on Voigt's Paper', Journal of Institutional Economics, 9(1): 27-29.

Shirley, M. M. (2013), 'Measuring Institutions: How to be Precise though Vague', Journal of Institutional Economics, 9(1): 31-33.

Sturm, J., E. Leertouwer, and J. de Haan (2002), 'Which Economic Freedoms Contribute to Growth? A Comment', Kyklos 55(3): 403-416.

Voigt, S. (2013), 'How (Not) to Measure Institutions', Journal of Institutional Economics, 9(1): 1:26. 